\title{
The Ewing's Sarcoma Family of Tumors of Urinary Bladder: A Case Report and Review of the Literature
}

\author{
Şenol Tonyalı ${ }^{1}$, Sertaç Yazıcı ${ }^{1}$, Aysun Yeşilırmak ${ }^{2}$, Ali Ergen ${ }^{1}$ \\ ${ }^{1}$ Department of Urology, Hacettepe University School of Medicine, Ankara, Turkey \\ ${ }^{2}$ Department of Pathology, Hacettepe University School of Medicine, Ankara, Turkey
}

Background: Only 15 cases of Ewing's Sarcoma (EWS) family of tumors of urinary bladder have been documented in the literature to date.

Case Report: We presented here a 38 year-old female with primary urinary bladder EWS with no distant metastases. She had presented with macroscopic hematuria and had undergone transurethral resection of the tumor within the following week. Microscopic examination revealed a tumor diffusely infiltrating the lamina propria and muscularis propria under an intact urothelium, which was composed of small round blue cells with scant cytoplasm, monotonous round or oval nuclei, stippled chromatin and small nucleoli. Immunohistochemistry showed strong vimentin, synaptophysin and membranous CD99 expression by the tumor. Fluorescent in situ hybridization analysis displayed the EWSR1 rearrangement. Radical cystectomy with total abdominal hysterectomy and bilateral salpingo-oophorectomy, extended lymph node dissection, and ileal conduit were performed. As adjuvant chemotherapy, she received vincristine, doxorubicin, cyclophosphamide and mesna, alternating with courses of etoposide, iphosphamide and mesna. She is alive and well with no evidence of disease 14 months after the surgery.

Conclusion: Surgery supported with chemotherapy should be considered as an option, especially in advanced Ewing's sarcoma family of tumors of urinary bladder.

Keywords: Ewing's Sarcoma, primitive neuroectodermal tumor, urinary bladder tumor
Tumors in the Ewing's sarcoma (ES) family develop in the bones or nearby soft tissues, and share some common features. Three main types of ES have been described: ES of the bone, extra-osseous (extra skeletal) ES and primitive neuroectodermal tumor (PNET).

Ewing family-type tumors, although ranked as the second most common sarcoma in bone and soft tissue in children, are rare, occurring in less than 3 in every one million people under the age of 20. Most of the patients are between 5 and 25 years of age, and it is extremely rare after the age of 25 (1). Ewing's sarcoma/Primitive neuroectodermal tumor (ES/PNET) can also rarely occur in visceral organs such as the liver, testis, uterus, kidney, ovary, parotid gland, lung, pancreas, urinary bladder, rectum, heart and gall bladder $(2,3)$. In the literature, only 15 cases of ES/PNET of the urinary bladder have been reported (4-10). We present here another case of primary ES/ PNET in the urinary bladder, which was locally invasive and had no metastases at the time of diagnosis.

\section{CASE PRESENTATION}

A 38 year-old woman was referred to our clinic with urinary bladder tumor in January 2014. Informed consent was obtained from the patient for using her data in scientific studies while protecting her anonymity. She had presented with macroscopic hematuria. Physical examination and routine blood parameters were normal. She did not have urine cytology or

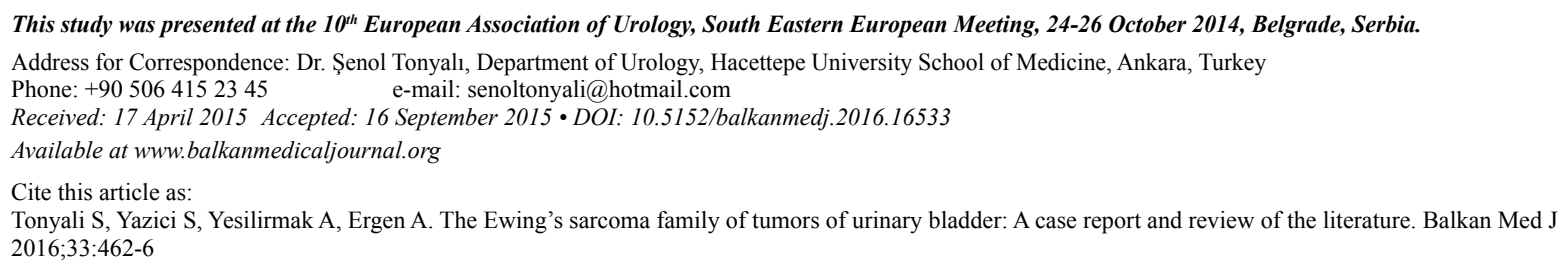




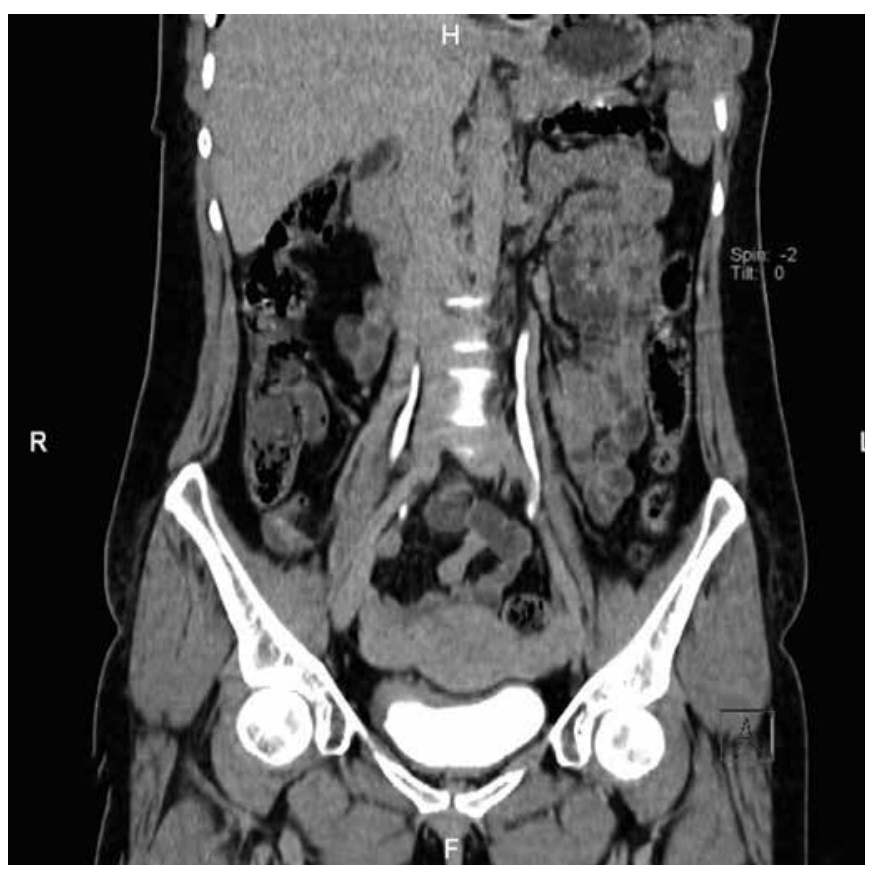

FIG. 1. Computed Tomography performed prior to radical cystectomy.

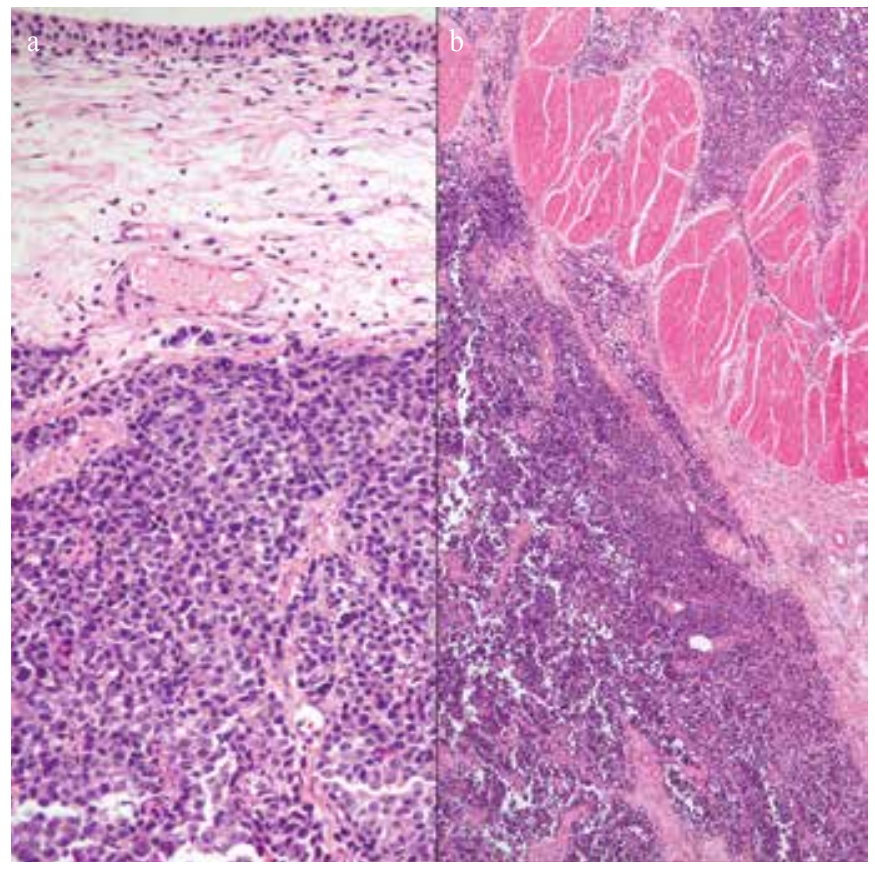

FIG. 2. a, b. Small blue round cell neoplasm underlying an intact urothelium (a) and infiltrating muscularis propria (b) (a: H\&E x200; b: H\&Ex40).

bone scans. The computed tomography imaging demonstrated a tumorous thickening in the wall of the urinary bladder posterolaterally at the right side, which was extending into perivesical fat tissue (Figure 1). No distant organ or lymph node metastases were detected. The complete transurethral resection of the tumor was performed within a week.

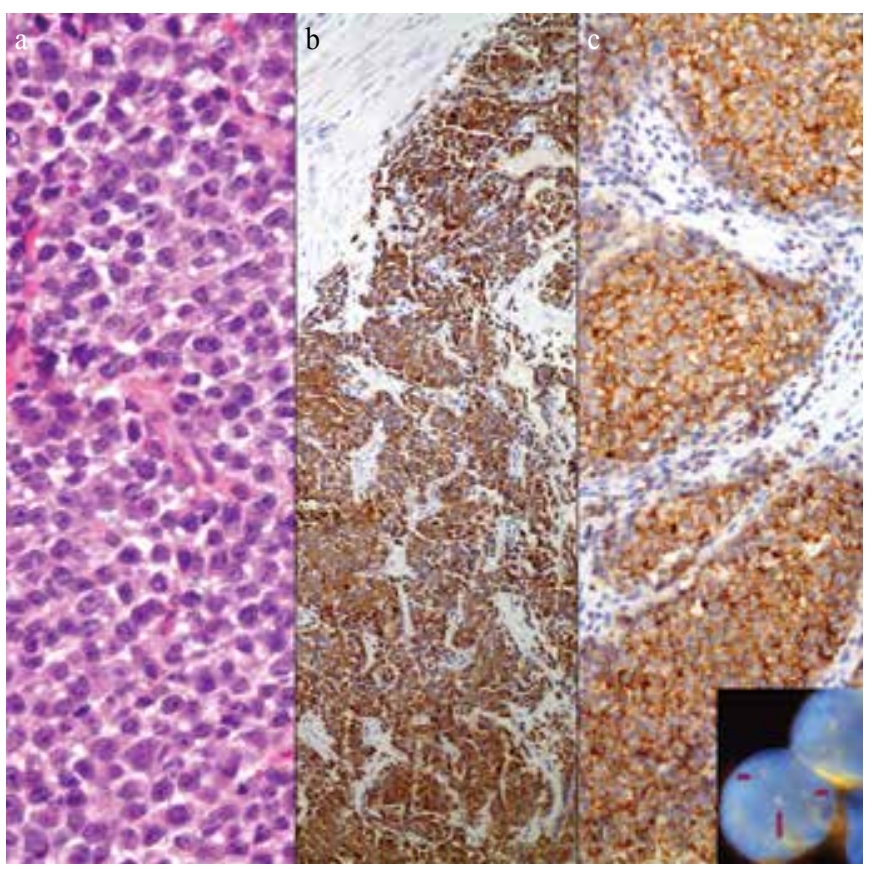

FIG. 3. a-c. Uniform neoplastic cells with round to oval nuclei and small nucleoli (a), tumor exhibited diffuse expression of synaptophysin (b) and membranous CD99 (c). Inset shows the result of FISH study with one juxtaposed (long arrow) and two setable parate (short arrows) red and green signals in the nucleus indicating translocation involving EWSR1 gene at 22q12 (a: H\&E x400; b: immunohistochemistry, anti-synaptophysin Ab x100; c: immunohistochemistry, anti-CD99 Ab x200; Inset: fluorescence in situ hybridization break apart assay for EWSR1 x1000).

Microscopic examination showed a tumor diffusely infiltrating the lamina propria and muscularis propria under an intact urothelium (Figure 2). It was composed of small round blue cells with scant cytoplasm, monotonous round or oval nuclei, stippled chromatin and small nucleoli (Figure 3). Neoplastic cells were arranged in solid sheets, nests, tightly packed cords and ribbons. Rosette formation was not evident, while mitotic activity was abundant. No surface papillary projections or in situ intraepithelial neoplasia was identified. Immunohistochemistry showed strong vimentin (Clone V9; dilution 1:100, Thermo Scientific; CA, USA), synaptophysin (Clone 27G12; dilution 1:100, Leica; Newcastle, England) and membranous CD99 (Clone H036-1.1; dilution 1:50, Biocare; CA, USA) expression by the tumor. Pan-cytokeratin (Clone AE1/AE3; dilution 1:100, Biocare; CA, USA), EMA (Clone E29; dilution 1:100, Biocare; CA, USA), GATA-3 (Clone L50-823; dilution 1:250, Biocare; CA, USA), chromogranin (Clone SP12; dilution 1:50, Thermo Scientific; CA, USA), CD56 [(neural cell adhesion molecule) (Clone 1b6; dilution 1:50, Leica; Newcastle, England)], S100 (Clone 4c4.9; dilution 1:100, Thermo Scientific; CA, USA), HMB-45 (Clone HMB45; dilution 1:60, Leica; Newcastle, England), desmin (Clone D33; dilution 1:50, Biocare; CA, USA), smooth muscle actin (Clone 
1a4; dilution 1:400, Neomarkers; CA, USA), leukocyte common antigen (Clone MEM28; dilution 1:200, Genemed, CA, USA), terminal deoxynucleotidyl transferase (Clone N/A; dilution 1:50, Biocare; CA, USA), inhibin (Clone R1; dilution 1:50, DBS, CA, USA), androgen receptor (Clone AR441; dilution 1:100, DBS; CA, USA) and SALL-4 (Sal-like protein 4) (Clone 6E3; dilution 1:100, Biocare; CA, USA) were negative. FISH analysis using the 22q12 LSI, EWSR1, Dual-Color Break-Apart Probe (ZytoVisio; Bremerhaven, Germany) was performed and displayed a 22q12 translocation pattern for the EWSR1 gene. The histomorphological findings, immunohistochemical profile and FISH results were found to be consistent with primitive neuroectodermal tumor/Ewing's sarcoma of the urinary bladder.

Radical cystectomy with total abdominal hysterectomy and bilateral salpingo-oophorectomy, extended lymph node dissection, and ileal conduit were performed. Pathological examination of the surgical specimen revealed a large residual tumor in the bladder $(4 \times 2.6 \times 2.5 \mathrm{~cm}$ in dimension) invading the perivesical fat tissue macroscopically. Microscopic examination was consistent with the previous diagnosis. Adjacent organ involvement or lymph node metastases were not identified. Surgical margins were free of the tumor.

The patient had no problems in the postoperative period and was discharged on the $6^{\text {th }}$ post-operative day. As adjuvant chemotherapy, she received vincristine, doxorubicin, cyclophosphamide and mesna, alternating with courses of etoposide, iphosphamide and mesna. Thorax and abdominal contrast-enhanced computed tomography performed 3, 6, 9 and 12 months after the surgery were completely free of tumor. The patient is alive and well with no evidence of disease 14 months after surgery.

\section{DISCUSSION}

Ewing's sarcoma/Primitive neuroectodermal tumor of the urinary bladder is a rare entity. It has not been possible to establish definitive guidelines regarding its management and treatment due to the very small number of reported cases; only 15 cases have been documented in the literature to date. Most of our knowledge on the treatment of this aggressive disease has been extracted from Ewing's sarcomas. The differential diagnosis in pathology can be made by immunohistochemistry, ultrastructural and molecular genetic analyses.

The review of the literature is summarized in Table 1 (4-10). The age of patients with primary ES/PNET in the urinary bladder ranged from 10 to 81, with a mean age of 44 . Hematuria was the most frequent presenting symptom. Additionally, some patients presented with bilateral hydronephrosis, renal failure and edema in lower extremities, which were associated with advanced disease. There was no gender tendency, with eight female and eight male patients.

Intravenous pyelography, magnetic resonance imaging, ultrasonography, computed tomography and bone scintigraphy were used as imaging studies at the diagnosis and patient evaluation. Five cases were metastatic at the time of diagnosis and 2 tumors had perivesical infiltration. Immunodeficiency has been reported as a risk factor for Ewing family tumors, similarly, in this population, five patients were immune-suppressed: one due to renal transplantation, one due to chemotherapy for squamous cell carcinoma of bladder, one due to Hodgkin's disease, one due to ALL (acute lymphoblastic leukemia), and one due to chemotherapy for another malignancy; this may confirm immunodeficiency as a risk factor.

Radical cystectomy was performed in 4 patients and partial resection in another 4 patients. One patient with a frozen pelvis was inoperable. The remaining patients were managed with transurethral resection or conservatively (4-10).

The diagnosis of primary ES/PNET in the urinary bladder is considerably difficult as it is an extremely rare disease in this location. Its differential diagnosis includes other small round cell malignancies, particularly small cell neuroendocrine carcinoma, embryonal rhabdomyosarcoma, small cell variant of malignant melanoma, non-Hodgkin lymphoma, synovial sarcoma, and desmoplastic small round cell tumor. These diagnoses can be ruled out in most cases if a relevant immunohistochemical panel is applied. Molecular analysis supports the final decision of ES/PNET by showing the EWS gene rearrangement via FISH, and the reciprocal translocation $\mathrm{t}(11 ; 22)$ (q24; q12) and EWS/FLI-1 fusion transcript via RT-PCR. This typical translocation is found in $85 \%$ of cases (11). The EWS gene rearrangement is seen also in desmoplastic small round cell tumor (DSRCT); however, its fusion partner in DSRCT is the WT-1 gene, not FLI-1. In fact, differentiating DSRCT from ES/PNET can be challenging at times because of the overlapping morphologic features. Nevertheless, immunohistochemistry will resolve the issue in most cases, as DSRCT will show nuclear WT-1 staining as well as paranuclear dotlike cytokeratin and/or desmin expression. Difficult cases may require molecular methods to document pertinent gene fusion products. The other translocation associated with ES/PNET in $10-15 \%$ of the cases is $\mathrm{t}(21 ; 22)$ (q22; q12) (12). Much more rarely, $\mathrm{t}(7 ; 22), \mathrm{t}(17 ; 22)$, and $\mathrm{t}(2 ; 22)$ translocations, as well as inv (22), have been described (13-15).

Advanced age, metastatic disease and limited resection may be related to poor prognosis. A multimodal approach is mandatory for the management of ES/PNET. Most patients with localized disease might have occult metastases; therefore, surgery must be supported by additional therapies (i.e. chemo- 
TABLE 1. Reported cases of urinary bladder Ewing's sarcoma/Primitive neuroectodermal tumor

\begin{tabular}{|c|c|c|c|c|c|c|c|}
\hline \multicolumn{8}{|l|}{ Cases } \\
\hline Reported & Sex & Age & Presentation & Medical history & Definitive Surgery & CTx & Survival \\
\hline 1.Banerjee et al., 1997 & M & 21 & $\begin{array}{l}\text { Microscopic hematuria, } \\
\text { dysuria }\end{array}$ & $\begin{array}{l}\text { Kidney transplantation, } \\
\text { immunosuppression }\end{array}$ & Cystectomy & $\begin{array}{l}\text { Vincristine-adriamycin- } \\
\text { cyclophosphamide }\end{array}$ & 18 months \\
\hline 2.Gousse et al., 1997 & $\mathrm{~F}$ & 15 & Macroscopic hematuria & $\begin{array}{l}\text { None } \\
\text { cystectomy }\end{array}$ & $\begin{array}{l}\text { TUR + partial } \\
\text { cyclophosphamide- } \\
\text { etoposide }\end{array}$ & Vincristine-doxorubicin- & 12 months \\
\hline 3.Desai, 1998 & $\mathrm{~F}$ & 38 & Gross hematuria & $\begin{array}{l}\text { RTx }+ \text { CTx for } \\
\text { Hodgkin's disease }\end{array}$ & $\begin{array}{l}\text { Cystectomy+ } \\
\text { TH+BSO }\end{array}$ & $?$ & $?$ \\
\hline 4.Mentzel et al., 1998 & M & 62 & $\begin{array}{l}\text { Fever, acute urinary } \\
\text { retention, backache }\end{array}$ & Anemia & Nephrostomy & - & Death \\
\hline 5.Colecchia et al., 2002 & $\mathrm{~F}$ & 61 & $\begin{array}{l}\text { Bilateral hydronephrosis } \\
+ \text { Renal failure }\end{array}$ & $\begin{array}{l}\text { DM, cardiac ischemia, } \\
\text { Mediterranean anemia }\end{array}$ & $?$ & $?$ & $?$ \\
\hline 6.Kruger et al., 2003 & M & 81 & $\begin{array}{l}\text { Lower extremities } \\
\text { lymphedema, fatigue, } \\
\text { urge incontinence }\end{array}$ & $\begin{array}{l}\text { Open enucleation of } \\
\text { prostate }\end{array}$ & $\begin{array}{l}\text { TUR + Bilateral } \\
\text { nephrostomy }\end{array}$ & None & 2 weeks \\
\hline 7.Ellinger et al., 2006 & M & 72 & $\begin{array}{l}\text { Gross hematuria, } \\
\text { oliguria } \\
\text { (unknown primary) }\end{array}$ & $\begin{array}{l}\text { CTx for left femoral } \\
\text { muscle tumor } \\
\text { wall met. resection } \\
\text { (frozen pelvis }+ \text { ) }\end{array}$ & $\begin{array}{l}\text { PLND, ileum } \\
\text { resection, abdominal }\end{array}$ & - & 2 months + \\
\hline 8.Lopez Beltran et al., 2006 & $\mathrm{~F}$ & 21 & $\begin{array}{l}\text { Gross hematuria, } \\
\text { dysuria, frequency }\end{array}$ & None & $\begin{array}{l}\text { Radical Cystectomy } \\
+\mathrm{TH}+\mathrm{BSO}\end{array}$ & $\begin{array}{l}\text { Adjuvant CTx } \\
\text { (unknown-1 year) + } \\
\text { maintenance with } \\
\text { imatinib }\end{array}$ & 36 months + \\
\hline 9. Osone et al., 2007 & $\mathrm{M}$ & 10 & Gross hematuria, dysuria & CTx for ALL & TUR & $\begin{array}{l}\text { Cyclophosphamide- } \\
\text { pirarubicin-vincristine } \\
(1,2,3,6 \text { cycles })+ \\
\text { iphosphamide-etoposide } \\
\text { (4,5,7 cycles) }\end{array}$ & 24 months + \\
\hline 10.Al Meshaan et al., 2009 & $\mathrm{~F}$ & 67 & Repeated hematuria & $\begin{array}{l}\text { CTx for bladder squamous } \\
\text { cell cancer }\end{array}$ & $\begin{array}{l}\text { TUR-Bt+ partial } \\
\text { cystectomy }\end{array}$ & $\begin{array}{l}\text { Unknown } 3 \text { courses CTx } \\
\text { for prior bladder tm } \\
\text { (not for PNET) }\end{array}$ & 8 months \\
\hline 11.Rao et al., 2010 & $\mathrm{~F}$ & 14 & $\begin{array}{l}\text { Lump in lower abdomen, } \\
\text { dull aching pain }\end{array}$ & None & $\begin{array}{l}\text { Sleeve resection of } \\
\text { bladder }\end{array}$ & $\begin{array}{l}3 \text { cycles undefined CTx } \\
\text { (after recurrence) }\end{array}$ & 6 months + \\
\hline 12. Busato et al., 2011 & $\mathrm{~F}$ & 52 & $\begin{array}{l}\text { Pelvic pain, dysuria, } \\
\text { frequency }\end{array}$ & None & TUR & $\begin{array}{l}\text { Doxorubicin-vincristine- } \\
\text { cyclophosphamide- } \\
\text { dactinomycin/etoposide/ } \\
\text { iphosphamide }\end{array}$ & 27 months + \\
\hline 13.Okada et al., 2011 & M & 65 & Gross hematuria, dysuria & HT, Cardiac ischemia & TUR-Bt & $\begin{array}{l}\text { Vincristine, iphosphamide, } \\
\text { doxorubisin, etoposide } \\
\text { (for lymph node recurrence); } \\
\text { cisplatin, etoposide/ } \\
\text { docetaxel (lung recurrence) }\end{array}$ & 22 months \\
\hline 14.Zheng et al., 2011 & M & 74 & $\begin{array}{l}\text { Frequency, dysuria, } \\
\text { hematuria }\end{array}$ & None & $\begin{array}{l}\text { Palliative surgery for } \\
\text { bleeding and biopsy }\end{array}$ & $\begin{array}{l}3 \text { courses epirubicin, } \\
\text { vincristine, } \\
\text { cyclophosphamide }\end{array}$ & 4 months \\
\hline 15.Sueyoshi et al., 2014 & M & 10 & $\begin{array}{l}\text { Polyuria, lower abdominal } \\
\text { swelling }\end{array}$ & None & Partial cystectomy & $\begin{array}{l}3 \text { courses neoadjuvant } \\
\text { and } 4 \text { courses adjuvant } \\
\text { vincristine, doxorubicin, } \\
\text { cyclophosphamide }+ \\
\text { ifosfamide, etoposide }\end{array}$ & 11 months + \\
\hline 16.Current case & $\mathrm{F}$ & 38 & Gross hematuria & None & $\begin{array}{l}\text { Radical cystectomy, } \\
\text { extended LND, } \\
\text { TAH+BSO }\end{array}$ & $\begin{array}{l}\text { Vincristine }+ \text { doxorubicin }+ \\
\text { cyclophosphamide }+ \text { mesna/ } \\
\text { etoposide, iphosphamide } \\
\text { +mesna }\end{array}$ & 14 months + \\
\hline
\end{tabular}

Rtx: radiotherapy; CTx: chemotherapy; Bt: bladder tumor; TH: total hysterectomy; BSO: bilateral salpingo-oophorectomy; DM: diabetes mellitus; TUR: transurethral resection; PLND: pelvic lymph node dissection; LND: lymph node dissection; HT: hypertension 
therapy). Doxorubicin-based chemotherapy regimens including cyclophosphamide, vincristine and dactinomycin have been associated with improved outcomes $(1,16)$. The addition of iphosphamide and etoposide to the standard regimen can also improve outcomes for non-metastatic Ewing's sarcomas/ PNET, but this is not effective in the case of metastatic disease (17). Although the response of sarcomas to high dose radiotherapy is well-defined, its use in ES/PNET of the bladder has not been well established yet (4).

Our case was a 38-year-old female with no comorbidities and risk factors. She had a locally advanced disease at the time of diagnosis. She had no distant metastases and no symptoms due to advanced disease. With the combination of radical surgery and adjuvant chemotherapy, she had 14 months of follow-up with no evidence of disease.

In conclusion, both clinician and pathologist must be aware of this rare entity during diagnosis and management. Surgery supported with chemotherapy should be considered an option, especially in advanced disease. With the description of new cases and long-term follow-up results, our knowledge and experience will improve.

\section{Ethics Committee Approval: N/A.}

Informed Consent: Written informed consent was obtained from patient who participated in this study.

Peer-review: Externally peer-reviewed.

Author contributions: Concept - S.T., S.Y, A.E.; Design - S.T., S.Y., A.Y., A.E.; Supervision - S.T., S.Y., A.E.; Resource - S.T., S.Y., A.Y.; Materials - S.T., S.Y., A.E.; Data Collection and/or Processing - S.T., S.Y., A.Y.; Analysis and/or Interpretation - S.T., S.Y., A.E.; Literature Search - S.T., S.Y., A.Y., A.E.; Writing - S.T., S.Y., A.Y., A.E.; Critical Reviews - S.T., S.Y., A.E.

Acknowledgements: Authors would like to thank to Dilek Ertoy Baydar for her kind support.

Conflict of Interest: No conflict of interest was declared by the authors.

Financial Disclosure: The authors declared that this study has received no financial support.

\section{REFERENCES}

1. Esiashvili N, Goodman M, Marcus RB Jr. Changes in incidence and survival of Ewing sarcoma patients over the past 3 decades: Surveillance Epidemiology and End Results data. J Pediatr Hematol Oncol 2008;30:425-30. [Crossref]
2. Mani S, Dutta D, De BK. Primitive Neuroectodermal Tumor of the Liver: A Case Report. Jpn J Clin Oncol 2010;40:258-62. [Crossref]

3. Bernstein M, Kovar H, Paulussen M, Randall RL, Schuck A, Teot LA, et al. Ewing's sarcoma family of tumors: current management. Oncologist 2006;11:503-19. [Crossref]

4. Busato WF Jr, Almeida GL, Ogata DC. Primary primitive neuroectodermal tumor of the bladder: histologic and clinical features of 9 cases. Clin Genitourin Cancer 2011;9:63-7. [Crossref]

5. Osone S, Hosoi H, Tanaka K, Tsuchiya K, Iehara T, Morimoto A, et al. A case of a ewing sarcoma family tumor in the urinary bladder after treatment for acute lymphoblastic leukemia. J Pediatr Hematol Oncol 2007;29:841-4. [Crossref]

6. Al Meshaan MK, Nayef M, Kwaider T, Otto W, Katchy KC. Peripheral primitive neuroectodermal tumor of the urinary bladder in an Arab woman with history of squamous cell carcinoma: a case report. J Med Case Rep 2009;3:6840. [Crossref]

7. Rao RN, Sinha S, Babu S, Mehrotra R. Fine-needle aspiration cytology of primitive neuroectodermal tumor of the urinary bladder: a case report. Diagn Cytopathol 2011;39:924-6. [Crossref]

8. Okada Y, Kamata S, Akashi T, Kurata M, Nakamura T, Kihara K. Primitive neuroectodermal tumor/Ewing's sarcoma of the urinary bladder: a case report and its molecular diagnosis. Int J Clin Oncol 2011;16:435-8. [Crossref]

9. Zheng Y, Tan F, Wang L, Xu N, Mou H. Primary primitive neuroectodermal tumor of the urinary bladder: a case report and literature review. Med Oncol 2011;28(Suppl 1):S388-91. [Crossref]

10. Sueyoshi R, Okawada M, Fujimura J, Saito M, Koga H, Lane GJ, et al. Successful complete resection of Ewing sarcoma arising from the bladder in a 10-year-old boy after chemotherapy. Pediatr Surg Int 2014;30:965-9. [Crossref]

11. Aurias A, Rimbaut C, Buffe D, Dubousset J, Mazabraud A. Chromosomal translocations in Ewing's sarcoma. $N$ Engl J Med 1983;309:496-7. [Crossref]

12. Sorensen PH, Lessnick SL, Lopez-Terrada D, Liu XF, Triche TJ, Denny CT. A second Ewing's sarcoma translocation, $\mathrm{t}(21 ; 22)$, fuses the EWS gene to another ETS-family transcription factor, ERG. Nat Genet 1994;6:146-51. [Crossref]

13. Jeon IS, Davis JN, Braun BS, Sublett JE, Roussel MF, Denny CT, et al. A variant Ewing's sarcoma translocation $(7 ; 22)$ fuses the EWS gene to the ETS gene ETV1. Oncogene 1995;10:1229-34.

14. Peter M, Couturier J, Pacquement H, Michon J, Thomas G, Magdelenat $\mathrm{H}$, et al. A new member of the ETS family fused to EWS in Ewing tumors. Oncogene 1997;14:1159-64. [Crossref]

15. Urano F, Umezawa A, Hong W, Kikuchi H, Hata J. A novel chimera gene between EWS and E1A-F, encoding the adenovirus E1A enhancer-binding protein, in extraosseous Ewing's sarcoma. Biochem Biophys Res Commun 1996;219:608-12. [Crossref]

16. Nesbit ME Jr, Gehan EA, Burgert EO Jr, Vietti TJ, Cangir A, Tefft $\mathrm{M}$, et al. Multimodal therapy for the management of primary, nonmetastatic Ewing's sarcoma of bone: a long-term follow-up of the First Intergroup study. J Clin Oncol 1990;8:1664-74.

17. Grier HE, Krailo MD, Tarbell NJ, Link MP, Fryer CJ, Pritchard DJ, et al. Addition of ifosfamide and etoposide to standard chemotherapy for Ewing's sarcoma and primitive neuroectodermal tumor of bone. N Engl J Med 2003;348:694-701. [Crossref] 